\title{
Douglas-fir Encroachment into Mountain Grasslands in Southwestern Montana
}

\author{
STEPHEN F. ARNO AND GEORGE E. GRUELL
}

\section{Abstract}

A study of plant succession in relation to disturbance history was conducted in Douglas-fir [Pseudotsuga menziesii var. glauca (Beissn.) Franco] forest and fescue (Festuca L. spp.) grassland communities along the eastern slope of the Continental Divide in Montana. The objective was to obtain ecological information needed for assessing management alternatives aimed at enhancing big game habitat and livestock forage. Fire history was reconstructed through analysis of fire scars and age classes of trees. Sizes and ages were inventoried in sapling stage, pole stage, and mature forest stands. Results indicate that prior to 1890 fires occurring every few decades favored grassland and confined tree growth to rocky or topographically moist sites. Since 1890 fires have been rare as a result of livestock grazing (which removes fine fuels), fire suppression, and cessation of ignitions by Native Americans. Lack of fire allowed extensive areas of Douglas-fir "invasion" now of pole size to become established in former grasslands between 1890 and 1915. Widespread invasion of sapling size trees occurred between 1941 and 1955, when seed crops apparently coincided with unusually favorable moisture conditions. For management of these areas, we recommend use of prescribed fire in conjunction with timber harvesting to enhance declining forage productivity for big game and livestock.

Previously, we reported that Douglas-fir [Pseudotsuga menziesii var. glauca (Beissn.) Franco] forests have expanded and thickened near the lower timberlines in southwestern Montana (Arno and Gruell 1983, Gruell 1983). In this paper we present information on the magnitude of Douglas-fir encroachment in mountain grasslands in a study area representative of this region. We examine the relationship of fire history to changes in age-class and size-class structure in both "invading" and old-growth forest stands, occurring on different forest habitat types (potential climax). Douglasfir is invading sites that were previously maintained as grasslands by periodic fires.

In 1983, a prescribed fire demonstration area was established on the Galena Allotment, Deerlodge National Forest, to test prescriptions for managing east-side Douglas-fir forests and mountain grasslands. Objectives were to enhance wildlife habitat (primarily for elk, Cervus elaphus L., and mule deer, Odocoileus hemionus Rafinesque), improve forage for livestock, and reduce wildfire hazard. National Forest and research personnel had observed the spread of Douglas-fir into mountain grasslands on the Galena area and recognized that continued tree encroachment would reduce forage production. However, there was a lack of detailed information on the ecological background of this invasion. Nearby oldgrowth Douglas-fir forests were dense, decadent, and contained little forage. These stands contained dying remnants of quaking aspen (Populus tremuloides Michx.) groves and overmature seral shrubs, indicating that they had previously supported considerable browse.

S. Arno is a research forester in the Prescribed Fire and Fire Effects Research Work Unit of the Intermountain Research Station, Forest Service, U.S. Department of Agriculture, located at the Intermountain Fire Sciences Laboratory, Missoula, Mont. 59807. At the time this study was conducted, G. Gruell was a research wild life biologist in the same unit; he is currently regional fuels management officer, Intermountain Region, Forest Service, Ogden, Utah 84401.

The authors are indebted to personnel of the Deerlodge National Forest for their assistance during this research effort, and to the following reviewers for their helpful comments: Stephen Barrett, Systems for Environmental Management, Missoula; Wendel Hann, Northern Region, USDA Forest Service; Richard Laven, Colorado State University; Walt Mueggler, Intermountain Research Station, USDA Forest Service; Earl Willard, University of Montana; and two anonymous referees.

Manuscript accepted 29 August 1985.
We conducted a brief study of the Galena area to collect quantitative information concerning plant succession relative to disturbance history. This information was needed as an ecological basis for assessing management alternatives, including tree harvesting and possible conversion back to open forest, savanna, or grassland. Such practices might also be applicable to other Douglas-fir and mountain grassland areas, which are widespread in the Northern Rockies.

\section{Study Area}

Galena Gulch Demonstration Area covers about 2,400 ha (6,000 acres) of mountainous terrain mostly between 1,680 and $2,010 \mathrm{~m}$ $(5,500$ and $6,600 \mathrm{feet})$ in elevation. The area lies about $5 \mathrm{~km}(3 \mathrm{mi})$ west of Boulder, Mont. (Fig. 1). It is part of the Boulder Batholith

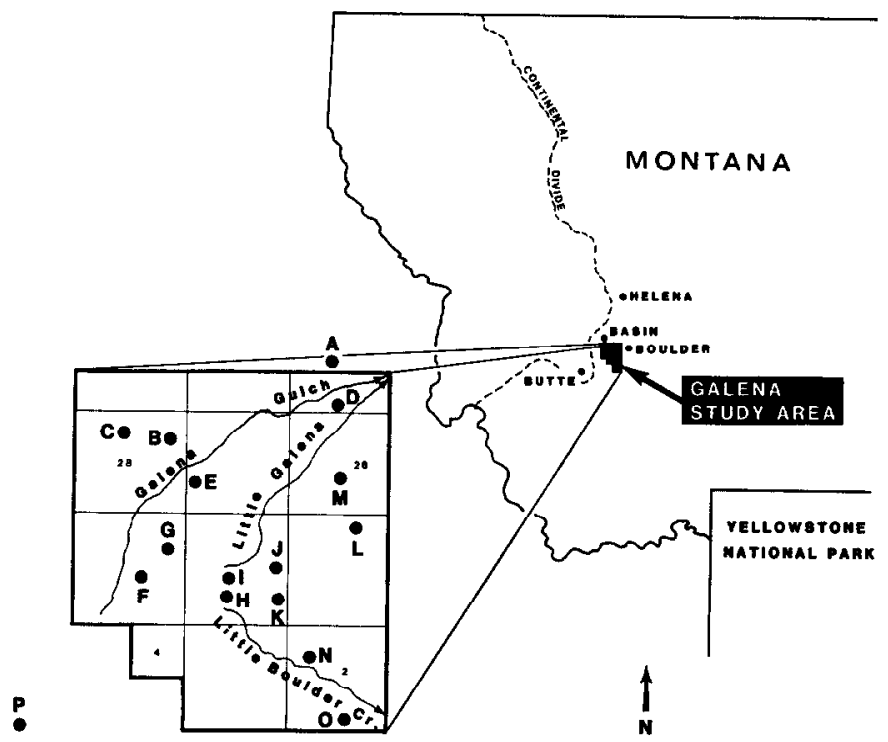

Fig. 1. Map of the Galena Study Area on a section-line (square mile) grid. Letters indicate fire history sample sites.

and consists primarily of a granite parent material that yields shallow, sandy soils. A cool, dry continental climate is characteristic, with annual precipitation averaging between 38 and $64 \mathrm{~cm}(15$ and 25 inches) but often fluctuating substantially from year to year. Forest now covers more than half of the area and is almost entirely Douglas-fir on drier sites and aspects, while lodgepole pine (Pinus contorta var. latifolia Engelm.) becomes prevalent on cool, moist north slopes and in drainage bottoms. Sagebrush-grasslands [Artemisia tridentata spp. vaseyana (Rydberg) Beetle, Festuca idahoensis Elmer, $F$. scabrella Torr., etc.] cover extensive areas on the broad upper slopes of the principal ridges. Many of these grasslands have been invaded by Douglas-fir, now of sapling size. Other large areas have nearly pure pole-size stands of Douglas-fir with skeletons of sagebrush in the understory.

Historically, the Galena area was frequented by Indians who were attracted by bison and other animals (Phillips 1940 and unpublished documents on Jefferson County livestock at the Montana Historical Society Library, Helena). Gold brought Euroamericans to the region in the 1860 's. Most soon tired of prospecting and 
some established homesteads in the major valleys below the study area. By the late 1870's, most of the arable land was occupied by ranches, and many thousands of head of cattle and horses were grazed in the nearby mountains. Galena Creek and Little Boulder River were particularly suited to grazing because of the gentle topography and expansive grasslands. Later a major sheep driveway was established across Galena and Little Galena creeks, and yearlong use was made by wild horses. Ranchers looked upon the forage as an unlimited resource that was there for the taking; hence, overgrazing was prevalent by the late 1800 's (Willard et al. 1983). Attendant with heavy grazing was logging that started in the 1870's. Many of the large trees were removed, while in some sites smaller trees were selectively cut for mine props and other uses.

Sites where conifer invasion has occurred belong to the Douglasfir/bunchgrass habitat types (h.t.) or Douglas-fir/pinegrass (Calamagrostis rubescens Buckl.) h.t., bunchgrass phase, based on potential climax vegetation (Pfister et al. 1977). These sites are henceforth referred to as "Douglas-fir/bunchgrass" h.t. Rough fescue (Festuca scabrella Torr.) is the primary bunchgrass indicator in the Galena area (cf. Mueggler and Stewart 1980), although its canopy coverage has been greatly reduced by livestock grazing and by succession to sagebrush and Douglas-fir.

\section{Methods}

Old growth trees as well as snags and stumps with fire scars were inventoried throughout most of the study area, using methods similar to those of Arno and Sneck (1977) (cf. McBride and Laven 1976, Kilgore and Taylor 1979, McBride 1983). The number of individual fire scars in each "catface" or multiple fire wound was recorded along with the soundness of the wood, and thus its ability to provide a datable record of fires. We chose an array of stands for sampling that represented north slopes, south slopes, and broad ridgetops. This consisted of 16 sample sites (Fig. 1) where longterm fire history could be reconstructed through analysis of fire scars and age classes of trees.

Cross-sections were cut from trees (usually from 2 trees per site) that showed the longest and most complete fire-scar record (Arno and Sneck 1977). Cross-sections were sanded and the individual fire scars dated, through counting of annual growth rings, and correlated into a master fire history chronology for each of the 16 sites. Periods of extremely slow growth and missing growth rings (sometimes following fire damage) in east-side Douglas-fir prevented exact determination of fire years even when scar dates were compared and correlated between nearby trees (Arno and Sneck 1977).

Reconnaissance plots were used to document tree succession in 18 stands of various ages located on 9 of the fire history sample sites. One $375-\mathrm{m}^{2}$ (nearly $\mathrm{l} / 10$ acre) circular macroplot was used for inventorying trees and estimating canopy coverage of undergrowth species. This macroplot was located in a representative portion of the stand using the "subjective without preconceived bias" reconnaissance approach described by Mueller-Dombois and Ellenberg (1974) and Pfister and Arno (1980). Age-class and size-class structure were recorded by tree species, and canopy coverages were estimated for each undergrowth species on the macroplots. Trees from each size class were cross-sectioned or increment bored near the ground line for age determination. This sampling allowed compilation of data representative of stand conditions throughout the study area.

The sapling stage (referred to as "sapling invasion") on the Douglas-fir/ bunchgrass h.t. designates stands of trees mostly 2 to $13 \mathrm{~cm}$ in diameter at breast height; pole stage (referred to as "pole invasion") is dominated by trees 18 to $30 \mathrm{~cm}$ in diameter. We sampled sapling invasion, pole invasion, and mature stands at each of 3 Douglas-fir / bunchgrass fire history sites. On 3 other Douglasfir/bunchgrass fire history sites we were able to locate and sample 2 of the above successional stages. One patch of Douglas-fir seedling invasion, with trees less than $1.5 \mathrm{~m}$ tall, was observed and sampled.
The moist north-slope sites, which have been continuously forested for several centuries, support both Douglas-fir and lodgepole pine, and they fit the Douglas-fir/pinegrass h.t., pinegrass phase. Three mature stands representative of these conditions were sampled (sites E, I, and $O$ in Fig. 1).

\section{Results}

\section{Fire History}

The fire years listed in the fire history chronologies for the 16 sample sites are approximate (Fig. 2), but as early as 1764 they appear to be within 1 year of the actual date, considering the close

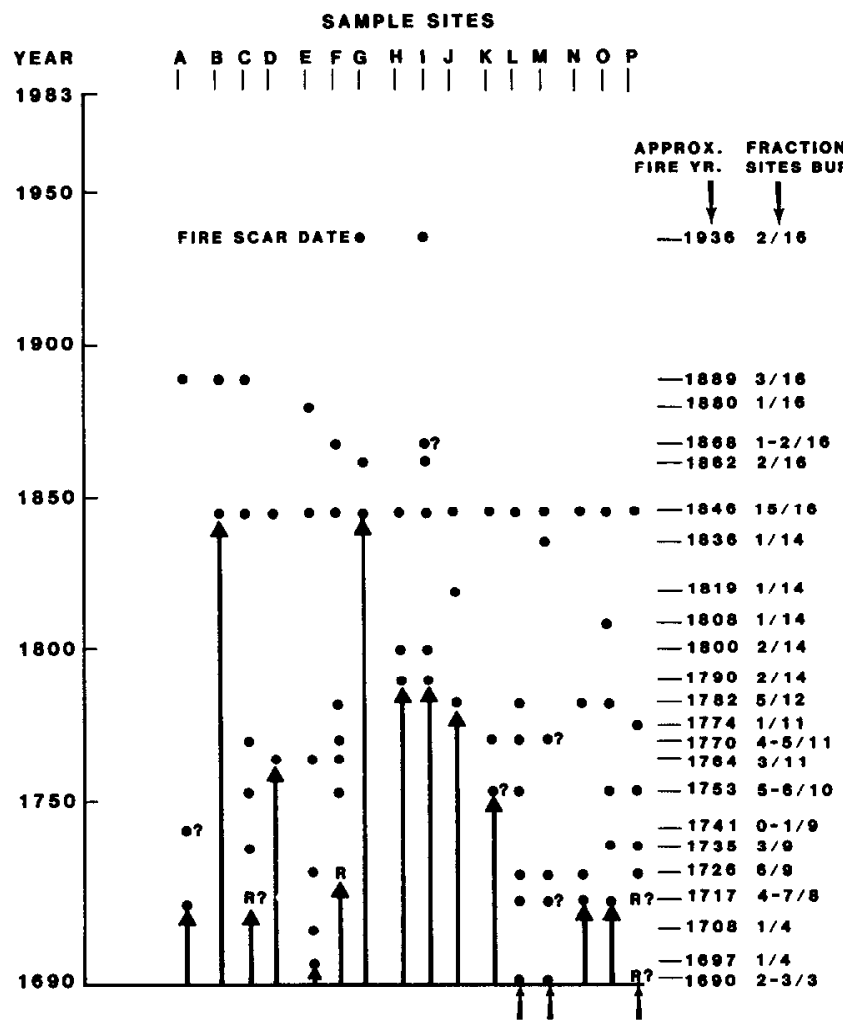

Fig. 2. Fire history chronologies at sample sites (locations shown on Fig. 1). Dots indicate fire scar dates; $\mathbf{R}=$ lodgepole pine regeneration dating to a fire year. Arrows indicate the beginning point of fire history records for each stand. Question marks indicate likely but uncertain fire evidence. "Fraction of sites burned" is the number of sites showing a given fire year over the total number of sites recording fire history at that time.

correspondence of fire scar dates from trees with the clearest growth-ring patterns. Prior to 1764 , fires are estimated to be within 3 years of the actual date. The pattern of fire occurrence and intervals between fires are sufficiently accurate for interpreting relationships between vegetation and past fires (cf. McBride 1983).

Each site's fire chronology (Fig. 2) begins with the earliest fire scar found on the site. When old lodgepole pines were present, the earliest fire was indicated by the initiation of an age class of this fire-dependent species (Arno and Sneck 1977). These data indicate that fires were frequent and widespread from about 1690 , the time of the earliest fire scars, until about 1800 . Only 3 small fires were recorded in the early 1800's. Then, in 18461 or perhaps more fires swept over virtually the entire area; nevertheless in many stands the overstory survived. After 1846, only 5 fire years were recorded from the sample trees. None of these was extensive in the study area although 1 of them, 1889, was a year of widespread wildfire in the Northern Rockies. In the 94 years after 1889, only 1 fire (1936) was recorded on the 16 sample sites.

In general, the longest fire intervals prior to 1890 were 72 to 82 years and occurred immediately preceding the 1846 fire. The short- 
est fire interval we were able to detect was at site $F$ where 1 tree was clearly scarred by 2 fires occurring only 6 years apart, in about 1764 and 1770.

Fires were widespread in the Galena area in the approximate years $1690,1717,1726,1753,1770,1782$, and 1846 . These fires burned in more than $40 \%$ of the stands with fire records. The resulting mean interval between major fires occurring within the entire Galena study area was 26 years. The longest intervals between such major fires were the 64 years prior to 1846 and the 137 years from 1846 to the time of the study in 1983.

\section{Forest Succession}

Mature stands sampled in the Douglas-fir/bunchgrass sites (A, $\mathrm{C}, \mathrm{H}, \mathrm{J}, \mathrm{K}$, and $\mathrm{L}$ in Fig. 1) were composed almost entirely of trees that originated between 1730 and 1880 along with a few individuals dating back to the 1500 's. The majority of trees in the mature stands became established in the long interval prior to the 1846 fire. The pole invasion became established primarily between 1890 and 1915, while the sapling invasion occurred between 1941 and 1955 (Figs. 3 and 4). The one seedling invasion stand originated mostly between 1965 and 1970.

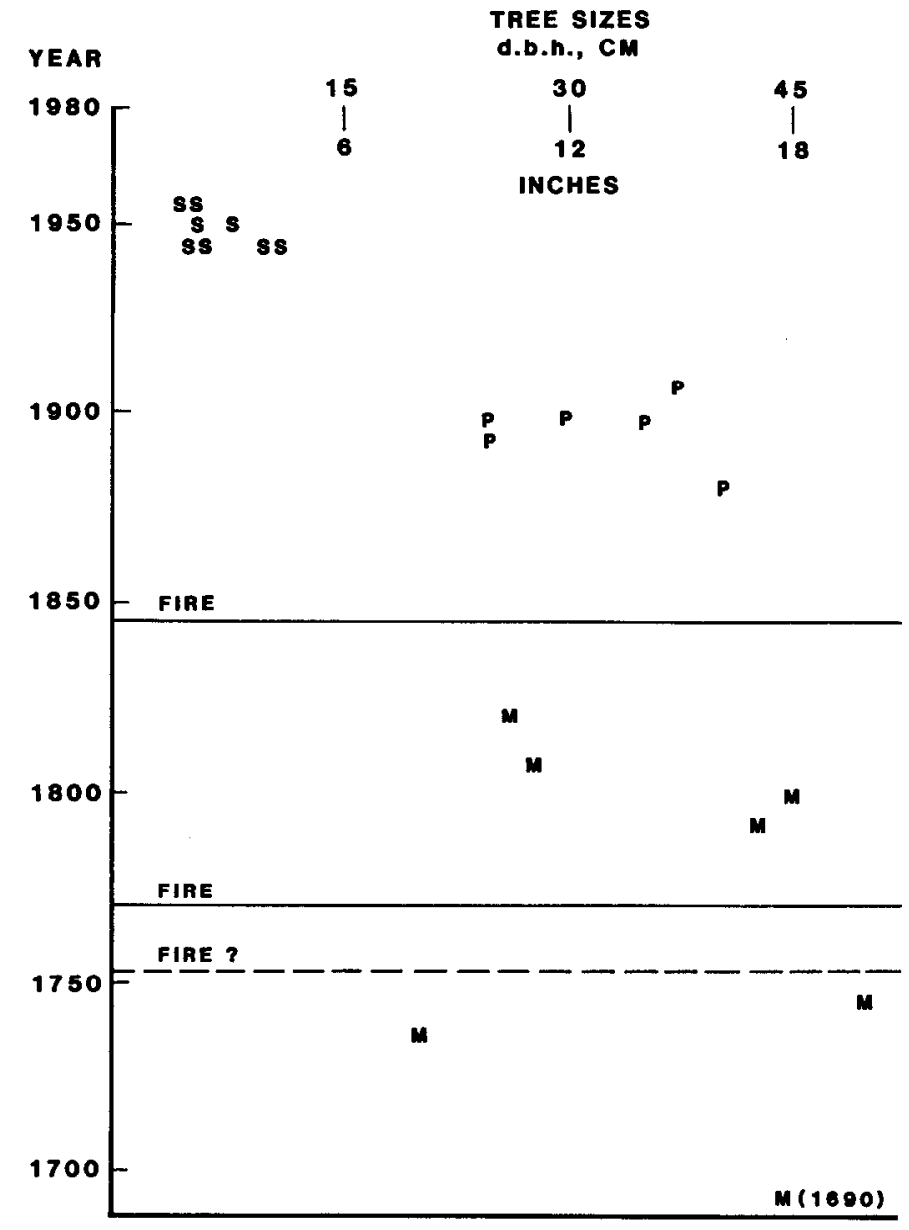

Fig. 3. Dates of establishment and sizes of trees sampled in 3 adjacent stands of different ages at site $K$ (Fig. I), Douglas-fir/bunchgrass h.t. $S^{\prime}$ represent trees in the sapling invasion stand; $P$ 's and $M$ 's are trees in pole invasion and mature stands, respectively. Past fires are indicated by horizontal lines.

In sample stands on the Douglas-fir/pinegrass-pinegrass sites (Fig. 5), dominant trees predate the 1846 fire and variable numbers of both Douglas-fir and lodgepole pine predate still earlier fires. There has been little effective regeneration in these stands during the past $\mathbf{1 0 0}$ years, and the overstory trees are severely stagnated as a result of overstocked conditions.

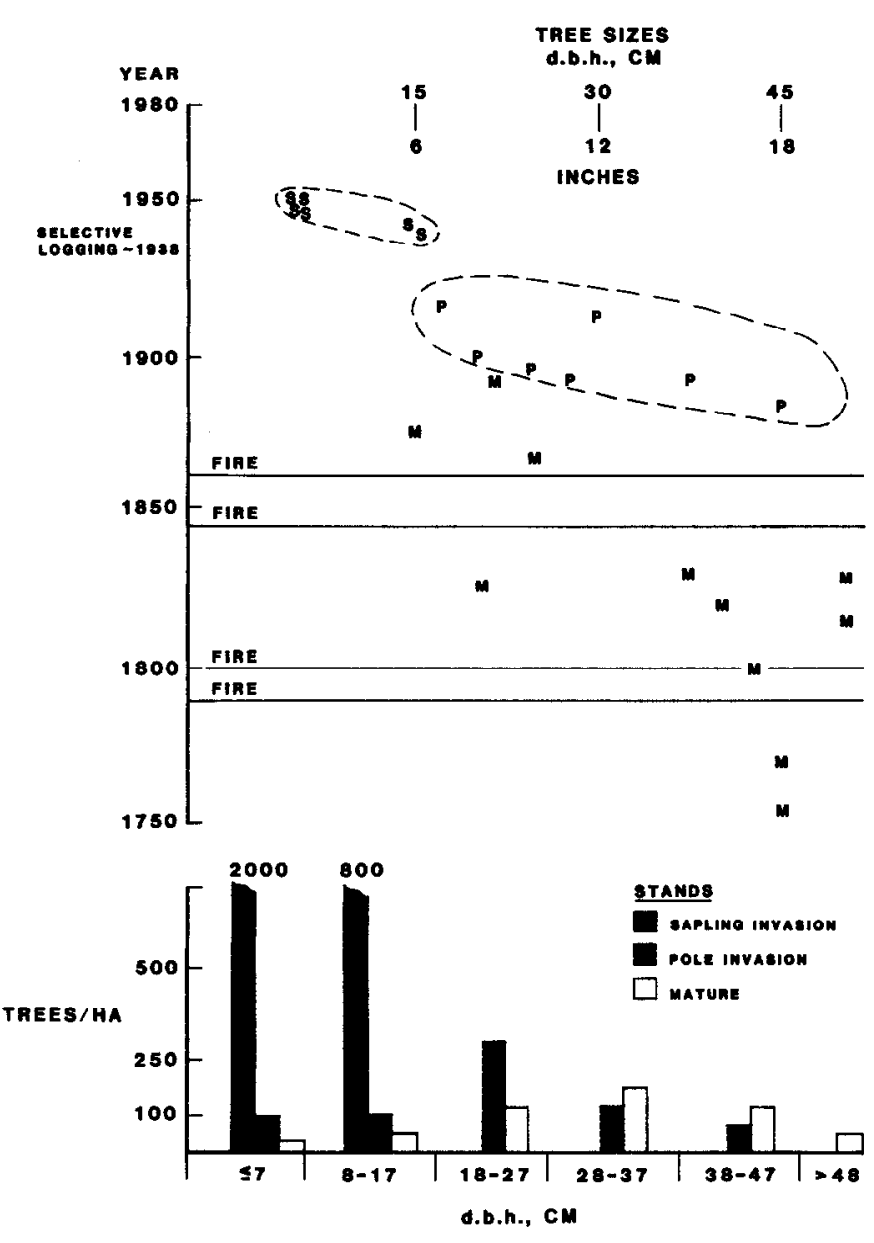

Fig. 4. Dates of establishment and sizes of trees sampled in 3 adjacent stands at site H(Fig. 1), Douglas-fir/bunchgrass h.t. S's represent trees in the sapling stand; $P$ 's and $M$ 's are trees in pole stand and mature forest, respectively. Past fires are indicated by horizontal lines. Bar graphs, below, show number of stems per hectare by size class for each stand.

\section{Discussion and Conclusions}

Between 1690 and 1800, fires were frequent and often extensive; the mean fire intervals at individual sample sites averaged 25 years. Fires were started by lightning and by American Indians (Barrett and Arno 1982, Gruell 1985). On the Douglas-fir/bunchgrass sites stand age information suggests that forest cover was much more limited than it is today. Trees were apparently confined to the rockiest sites where understory fuels were sparse. Ring-width chronologies from old Douglas-fir trees on a severely droughty site $55 \mathrm{~km}$ northeast of the Galena area (Stokes et al. 1973) suggest that the overall climate from 1690 to 1800 did not differ much from that of more recent times.

Between 1800 and 1845 (or perhaps 1782 and 1845) only a few small fires occurred in the study area. Tree ring-width data (Stokes et al. 1973) suggest that the overall climate was not remarkably wet or dry. Available moisture evidently was consistently below normal from 1792 through 1809 , but from 1821 through 1837 was higher than average. In any case, a large proportion of the trees in our mature sample stands became established during this long fire-free interval.

The 1846 fire spread through the study area no doubt aided by a buildup of both dead and living (ladder) fuels. During that year, 90\% of the individual fire history sample trees were scarred. Growth-ring chronologies (Stokes et al. 1973) suggest that 1846 was an exceptionally dry year, as were 1889,1783 (same as the ca. 1782 fire year?), and 1770 when other widespread fires occurred.

From 1846 to 1889 only 4 relatively small fires were recorded in 

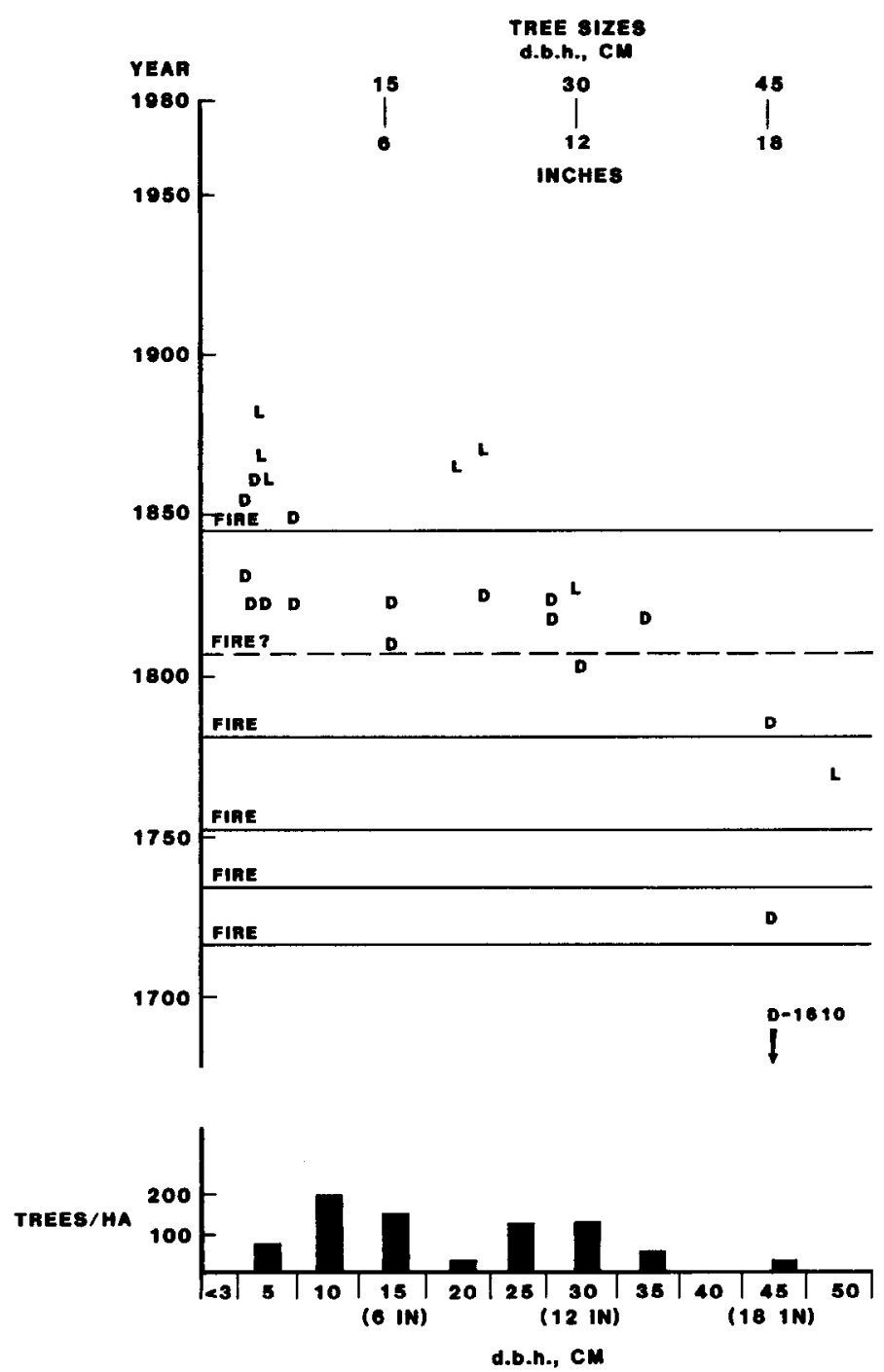

Fig. 5. Dates of establishment and sizes of trees sampled in a mature stand on the Douglas-fir/pinegrass h.t. (site 0 , Fig. 1). D's represent the Douglas-fir trees; L's are lodgepole pine. Past fires are indicated by horizontal lines. Bar graph, below, shows number of stems per hectare by size class.

the 16 sample sites. In this period, the Indians' nomadic lifestyle was greatly altered by the influx of Euroamericans and by the destruction of free-ranging bison. This largely removed the Indian as a source of ignition. Prospecting and mining activity became intense in this general area in the 1860 's but evidently did not result in an increase in fires at Galena.

Livestock use of the Galena grasslands, beginning in the 1860 's, apparently had a marked influence on fire occurrence. The effect of grazing in removing fine fuels can be visualized today by comparing grazed and ungrazed ranges. Recent measurements on a mountain grassland in the Galena study area showed that rough fescue in a livestock/ big game exclosure was producing $3,090 \mathrm{~kg} / \mathrm{ha}(2,760$ $\mathrm{lb} /$ acre). In contrast, an adjacent grazed site produced only 773 $\mathrm{kg} / \mathrm{ha}$. Recent applications of prescribed fire at Galena indicate that grazing hampers fire spread. Thus, it is highly probable that the more intense use by early-day livestock greatly restricted frequency and size of fires. The degree of this grazing influence on fine fuels is suggested by a 1922-1923 range appraisal for the Deerlodge National Forest that states: "Fire hazard on the Forest is so light as to be negligible. No fires have occurred on this forest for years...." (Taylor 1923).

The large areas of pole invasion that became established between about 1890 and 1915 may be partly related to heavy livestock grazing pressure. Also, tree ring-width chronologies (Stokes et al. 1973) suggest that most of this period had near-normal or betterthan-normal moisture conditions. Other observations of Douglasfir/grassland ecotones suggest that pole invasion of similar age is quite extensive in southwestern Montana (Arno and Gruell 1983, Gruell 1983).

Reasons for the decline in conifer establishment after 1915 are not clear. However, drought was common starting in 1918 and prevalent from 1930 through 1940 (Stokes et al. 1973). A new wave of conifer regeneration, the current sapling invasion, began in 1941 and continued until 1955. In some localities the pole invasion of 1890 to 1915 probably was the seed source for the saplings.

Previously Sindelar (1971) identified widespread Douglas-fir sapling invasion dating from the same period at several locations in southwestern Montana. He attributed this to good seed crops that coincided with unusually moist spring weather during several years. He found that most conifer invasion was associated with heavy livestock grazing, which had resulted in an increase in the coverage of sagebrush in former grasslands. This would also have been associated with a decrease in grasses (fine fuels) in both grasslands and adjacent forests.

The reason that this sapling invasion stopped is not known (Sindelar 1971). Perhaps the dramatic increase in damage to Douglas-fir cone crops by the western spruce budworm (Choristoneura occidentalis Freeman) beginning in the mid-1950's was a factor (Carlson et al. 1983, Chrisman et al. 1983). The continuing absence of fire is implicated as a factor that allowed the budworm to develop into a chronic epidemic status (Carlson et al. 1983).

Land managers and the public often fail to recognize that large areas of grasslands in the Rocky Mountains have been invaded by Douglas-fir (Gruell 1983). The magnitude of forest encroachment is indicated by a recent comparison of data from $\mathbf{4 0}$ survey corners (including 135 witness trees) in the Galena vicinity (Charles Bushey, Intermountain Fire Sciences Laboratory, Missoula, Mont., manuscript in preparation). In 1878, when the original survey was made, $48 \%$ of the corners fit tree density criteria indicative of forest growth. In contrast, when the corners were relocated in 1984, $75 \%$ of them met the same "forest" criteria.

The episodes of tree invasion undoubtedly reduced carrying capacity and forage for livestock and big game. Continued thickening of the tree and sagebrush cover will result in increased animal competition for available forage. Although the invading trees are of poor form and low value for sawtimber, they can be used for firewood and pulpwood. The more moist Douglas-fir/pinegrass sites are generally occupied by crowded, stagnated stands.

National Forest management direction emphasizes the wildlife and livestock resources in this Douglas-fir/mountain grassland zone. Thus, it seems appropriate to harvest timber in a manner that would complement wildlife habitat and livestock needs. Prescribed fire could be a desirable component of management practices. Underburning in selectively cut stands and broadcast burning on clearcuts would reduce slash and allow rejuvenation of forage plants. In contrast, continued lack of both fire and tree cutting in these Douglas-fir stands results in continued losses in forage productivity and habitat diversity.

\section{Literature Cited}

Arno, S.F., and G.E. Gruell. 1983. Fire history at the forest-grassland ecotone in southwestern Montana. J. Range Manage. 36:332-336.

Arno, S.F., and K.M. (Davis) Sneck. 1977. A method for determining fire history in coniferous forests of the mountain West. USDA Forest Serv. Gen. Tech. Rep. INT-42.

Barrett, S.W., and S.F. Amo. 1982. Indian fires as an ecological influence in the Northern Rockies. J. Forestry 80:647-651.

Carison, C.E., D.G. Fellin, and W.C. Schmidt. 1983. The western spruce budworm in Northern Rocky Mountain forests: A review of ecology, past insecticidal treatments and silvicultural practices. p. $76-103 \mathrm{In}$ : J. O'Loughlin and R.D. Pfister (eds.) Management of Second-growth Forests: The State of Knowledge and Research Needs. Montana Forest and Conserv. Exp. Sta., Univ. of Montana, Missoula. 
Chrisman, A.B., G.M. Blake, and R.C. Shearer. 1983. Effect of western spruce budworm on Douglas-fir cone production in western Montana. USDA Forest Serv. Res. Pap. INT-308.

Gruell, G.E. 1983. Fire and vegetative trends in the Northern Rockies: interpretations from 1871-1982 photographs. USDA Forest Serv. Gen. Tech. Rep. INT-158.

Gruell, G.E. 1985. Indian fires in the Interior West: A widespread influence. P. 68-74. In: J.E. Lotan et al. (tech. coords.) Symposium and Workshop on Wilderness Fire. USDA Forest Serv. Gen. Tech. Rep. INT-182.

Kilgore, B.M., and D. Taylor. 1979. Fire history of a sequoia-mixed conifer forest. Ecology 60:129-142.

McBride, J.R. 1983. Analysis of tree rings and fire scars to establish fire history. Tree-Ring Bull. 43:51-67.

McBride, J.R., and R.D. Laven. 1976. Scars and indicators of fire frequency in the San Bernardino Mountains, California. J. Forest. 74:439-442.

Mueggler, W.F., and W.L. Stewart. 1980. Grassland and shrubland habitat types of western Montana. USDA Forest Serv. Gen. Tech. Rep. INT-66.

Mueller-Dombois, D., and H. Ellenberg. 1974. Aims and methods of vegetation ecology. John Wiley and Sons, New York.
Prister, R.D., B.L. Kovalchick, S.F. Arno, and R.C. Presby. 1977. Forest habitat types of Montana. USDA Forest Serv. Gen. Tech. Rep. INT-34.

Pfister, R.D., and S.F. Amo. 1980. Classifying forest habitat types based on potential climax vegetation. Forest Sci. 26:52-70.

Phillips, P.C. (ed.) 1940. W.A. Ferris: Life in the Rocky Mountains (Diary of the Wanderings of a Trapper in the Years 1831-1832). Old West Publ. Co., Denver, Colo.

Sindelar, B.W.1971. Douglas-fir invasion of western Montana grasslands. Ph.D. Diss., Univ. Montana, Missoula.

Stokes, M.A., L.G. Drew, and C.W. Stockton ed. 1973. Tree-ring chronologies of westem America: 1. Selected tree-ring stations. Univ. Arizona, Lab. of Tree-ring Res.

Taylor, J.B. 1923. Range appraisal summary report 1922-23, sheep and goat ranges. p. 14, Office rep. on file at Deerlodge National Forest, Butte, Mont.

Willard, E.E., D.J. Bedunah, and W. Hann. 1983. Forage and livestock in western Montana. In: J. O'Loughlin and R.D. Pfister, (eds.). Management of Second-growth Forests-the State of Knowledge and Research Needs. Montana Forest and Conserv. Exp. Sta., Univ. of Montana, Missoula. 